Јаромир Л. ЛИНДА*

Универзитет у Београду

Филолошки факултет

Катедра за славистику

\title{
АЛЕКСАНДАР БЕЛИЋ И ЧЕШКА СЛАВИСТИКА
}

\begin{abstract}
У студији обраћамо пажњу на односе између Александра Белића и чешких слависта (Бохуслав Хавранек, Јулијус Хајденрејх, Вилем Матезијус, Јиржи Хорак) као и слависта коју су у то доба живели у Чехословачкој (Матија Мурко, Јевгениј Александрович Љацки), при чему полазимо пре свега од необјављене кореспонденције која се чува у чешким и српским архивима, као и тадашње штампе. Посебну пажњу посвећујемо боравку Александра Белића у Прагу 1936. године, када је одржао неколико предавања у Словенском институту и на Карловом универзитету, као и његовом односу према Прашком лингвистичком кружоку. У прилогу објављујемо текст Резолуције Комисије за функционално-структурално истраживање словенских језика из 1929. године, као и синопсис предавања о Вуку Караџићу из 1936. године.

Кључне речи: Александар Белић, Карлов универзитет у Прагу, Словенски институт у Прагу, Прашки лингвистички кружок, Бохуслав Хавранек, Јулијус Хајденрејх, Вилем Матезијус, Јиржи Хорак, Матија Мурко, Јевгениј Александрович Љацки, Видосава Љацка.
\end{abstract}

Донедавно смо о сарадњи Александра Белића - без сумње најзначајнијег српског лингвисте двадесетог века - са лингвистима и славистима у Чехословачкој, било чешког или страног порекла који су у Прагу нашли и привремено и трајно уточиште, имали само случајне и непотпуне информације. Пажња се већином усмеравала пре свега на припрему и њихово учешће на неодржаном Трећем међународном конгресу слависта у Београду 1939. године, чија организација је већим делом била на плећима управо Белића (Станковић 2008). Тек едиција сачуване кореспонденције Александра Белића у чешким и српским архивима омогућила је поглед у узајамне контакте са чешким, руским, словеначким и српским колегама који су живели и радили у Прагу и Брну - са Бохуславом Хавранеком, Јиржијем Хораком, Видосавом Љацком, Јевгенијем Александровичем Љацким, Вилемом Матезијусом и Матијом Мурком, као и њихов детаљнији опис (Линда 2017). Реч је о писмима из периода 1924-1956. године, којих има укупно 61, и која су до сада била непозната,

\footnotetext{
*jaromirlinda@fil.bg.ac.rs
} 
а нуде потпуно нови поглед на сарадњу Александра Белића и слависта тадашње Чехословачке.

Први сачувани контакти Александра Белића са чешким лингвистима и славистима страног порекла који су живели у Прагу датирају из периода након Првог светског рата. Не искључујемо притом могућност да се Белић са некима од њих упознао још раније, током свог студијског боравка у Лајпцигу. Посебно је таква претпоставка вероватна у вези са професором Олджихом Хујером (Oldřich Hujer), индоевропеистом, коме је већ 1922. године Белић понудио чланство у уређивачком одбору „Јужнословенског филолога”. Хујер је одмах након ступања на ову дужност за „Јужнословенски филолог” припремио преглед чешке лингвистике за последњих дванаест година (Хујер 1922-1923). Белић је и у наредним годинама посвећивао пажњу Хујеру - у истом часопису је 1924. године објавио рецензију Хујерове књиге Úvod do dějin jazyka českého (Белић 1924), а у „Народној енциклопедији српско-хрватско-словеначкој” му је посветио биографски медаљон, који је касније прештампан у „Јужнословенском филологу” (Белић 1930). Међутим, њихову претпоставњену преписку нисмо успели да пронађемо.

Други слависта са којим је вероватно Александар Белић одржавао контакт још пре Првог светског рата је Словенац Матија Мурко. Он је 1920. године прешао из Лајпцига у Праг на Карлов универзитет, премда најстарије данас познато писмо потиче тек из 1924. године. Индиректно на то указује Белићева рецензија Муркове књиге Kroaten und Serben из 1907. године (Белић 1907), као и Белићева студија о прасловенском језику објављена 1922. године u првом броју часопис „Slavia”, који су заједно основали управо Мурко са Хујером (Белић 1922). Из сачуване кореспонденције можемо закључити да је Мурко, од двадесетих година 20. века па све до краја свог живота, спадао у најближе сараднике Александра Белића у иностранству.

Први пут је Белић у Прагу предавао вероватно јесени 1925. године. У писму из јуна 1925. реагује на позив прашког Филозофског факултета који му је упутио Матија Мурко и прецизира да би у Праг дошао у новембру на три седмице или месец дана (Линда 2017: 175). Нажалост, немамо (за сада) ближе информације о овој Белићевој посети Прагу. Три године касније, у мају 1928. године, Белић се по повратку из Прага Мурку извињава да није знао за његову жељу да у Прагу одржи предавање и предлаже му да дође у октобру или новембру (Линда 2017: 178). Да ли се на крају остварила ова Белићева посета Прагу, не знамо.

Од суштинског значаја за будуће односе између Александра Белића и лингвистима и славистима у тадашњој Чехословачкој је његово учешће на Првом конгресу словенских филолога, одржаном у Прагу од 6. до 13. октобра 1929. године. Управо 
је овде своје „Тезе” представио Прашки лингвистички кружок, и управо ту су биле, како је написао Роман Јакобсон, „истакнуте основне промене концепције у славистици" (Toman 2017: 46).

Александар Белић је 6. октобра на свечаном отварању у Сметаниној дворани поздравио окупљене у име југословенских учесника Конгреса (Белић 1932: $163-$ 165), а одмах наредног дана је на пленарном заседању представио уводни и главни реферат Конгреса посвећен словенској лингвистичкој библиографији, теми којом се интензивно бавио као главни уредник часописа „Јужнословенски филолог”. Уз то је дао значајан допринос својим учешћем у дискусијама у оквиру лингвистичке секције и то нарочито наступима везаних за „Тезе” Прашког лингвистичког кружока. Тако је у понедељак 7. октобра дао своје мишљење о првој (Методички проблеми који проистичу из поимања језика као система и значај таквог поимања за словенске језике) и другој тези (Задаци проучавања језичког система, посебно словенског), затим дан касније о тези четири (Актуелни проблеми црквенословенског језика) и у среду 9. октобра дао је коментар на шесту (Принципи лингвистичке географије, њена примена и однос према етнографској географији на словенском простору) и седму тезу (Проблеми свесловенског лингвистичког атласа, посебно лексичког). Истог дана дискутовао је у оквиру педагошко-дидактичке секције о осталим тезама Прашког лингвистичког кружока - нпр. о тези бр. 2 у вези са увођењем нових лингвистичких смерова у средње школе (Rejnková 1968: 9-12, 17, 24-25).

О веома битној улози Александра Белића на овом Конгресу сведочи и чињеница да се нико од иностраних учесника није укључивао у дискусију у толикој мери као он; по броју коментара и доприноса у дискусији му је био раван једино чешки етнограф и историчар књижевности Јиржи Хорак (Jiř́ Horák). Вредна је помена чињеница да је управо прецизан Белићев реферат о току Конгреса, објављен у „Јужнословенском филологу" одмах по његовом повратку, најдужи и најдетаљнији од свих тадашњих савремених приказа како међународних, тако и чешких (Белић 1929).

Не изненађује, стога, што су се чланови Прашког лингвистичког кружока трудили да српског лингвисту привуку у своје редове; један од конкретних резултата Првог конгреса словенских филолога било је и оснивање Комисије за функционално-структурално истраживање словенских језика са издвајањем четири главна задатка које објављујемо у прилогу број 1. Поред Александра Белића, чланови комисије били су: Витолд Дорошевски (Witold Doroszewski) из Варшаве, Бохуслав Хавранек (Bohuslav Havránek) из Брна, Роман Јакобсон (Roman Jakobson) из Прага, Сергеј Јосифович Карцевски (Sergej Josifovič Karcevskij) из Женеве, Вилем Матезијус (Vilém Mathesius) из Прага, Казимјерж Нич (Kazimierz Nitsch) из Кракова, Стојан Романски (Стоян Романски) из Софије, Васиљ Симович (Vasilj Simovyс̌) из Прага и Николај Сергејевич Трубецки (Николай Сергеевич Трубецкой) из Беча, дакле најеминентнији лингвисти тадашњег словенског света.

Комисија се први пут састала поводом међународне фонолошке конференције коју је Прашки лингвистички кружок сазвао у Прагу од 18. до 21. децембра 1930. Белић је тада имао предавање о акценту у речи и реченици (Belić 1931), а на одвојеном састанку 20. децембра друго предавање на тему система конјугација руских глагола. Комисија се други пут састала у Женеви 28. августа 1931. године током Другог међународног лингвистичког конгреса, који се ту одржавао од 25. до 29. 
августа. Током председавања Александра Белића разматрала се израда програма од шест тачака, при чему су Белић и професори Дорошевски и Симович обећали да ће написати фонолошке и морфолошке радове у области матерњих језика.

Још током заседања Комисије Белић је схватио да се у многим ставовима разилази са члановима Прашког лингвистичког кружока. Занемаримо ли назнаке тог става у његовом реферату о прашком заседању објављеном у „Јужнословенском филологу" (Белић 1931) најискреније је то изразио у личном писму Франу Рамовшу од 9. јануара 1931. године које бисмо овде радо цитирали:

„Сада о Прагу. Ишао сам тамо, што сам хтео овоме да посветим неколико дана, јер иначе не бих имао времена. У Прагу се показало да је ствар мало луда. Кад смо их доводили ad absurdum, они су говорили /(Јакобсон) да треба веровати да је тако или да се све не може доказати (Трубецки). Ово је система више математике, са свом њеном априорношћу, само без њене тачности у извођењу. Они сматрају да је De Saussure altes Zeug, да је све у алтернацијама и односима итд.

Две су ствари изашле на површину: 1) да и они сами не могу да одреде шта је то фонема; и 2) да има у језику 'целисходности'.

Али мени је сасвим друго изашло пред очи за све време седница. Изгледало ми као да би они хтели да 'прокљују' подсвест; да утврде оне 'законе' који владају језичким „законима и изменама у језику. Засада су узели звук тј. фонему, јер мисле да ће се на њему моћи показати основне ствари. Али се одмах ту показало да се у језику саusae finales могу знати само по ономе што се у језику јавља и чим се пође изван тога или почне приписивати томе неки нарочити значај - онда се удаљавамо од језика. Све је у језику повезано и све у језику ума свој смисао - то је њихов постулат који и ја примам; али не примам да је то 'све' једно мистично биће или један флуид који цео устрепери при најмањој модификацији ма на којој страни...” (Rotar 1990: 41-42).

У наредним активностима Комисије за функционално-структурално истраживање словенских језика Белић није учествовао. Не сумњамо у то да су сарадња, али и посебно неслагање са неким постулатима Прашког лингвистичког кружока имали великог утицаја на следеће Белићеве радове, пре свега његову „Општу лингвистику”. Једини конкретан штампани исход из периода 1929-1930, када га са пуним правом можемо сврстати у тзв. шири круг чланова Прашког лингвистичког кружока (званичним чланом ће постати тек 1948. године), представља рад „Sur l'accent du mot et de la phrase" (Belić 1931), чији текст је уосталом морао Вилем Матезијус код Белића да ургира (Линда 2017: 173).

Могуће је да су овај Белићев одступ и, дипломатским језиком речено, извесна суздржаност према Прашком лингвистичком кружоку допринели томе да је прошло више од пет година до следеће званичне посете Прагу. Почетком 1936. године Белић је позван да на прашком универзитету одржи укупно шест предавања на различите теме, а превасходно из опште лингвистике. Немамо информација о позадини овог позива, могуће је да је он дошао од стране Прашког лингвистичког кружока, чији чланови су предавали на Филозофском факултету Карловог Универзитета, као на пример од поменутог Матезијуса, али није искључено да је позив стигао и од других професора Филозофског факултета који нису били чланови Прашког лингвистичког кружока - од Олджиха Хујера или Јиржихо Хорака. Белић је у Праг стигао 
19. марта, а остао је до 5 априла, дакле приближно четрнаест дана. Био је смештен у чувеном хотелу Париз у Старом Граду.

Иако постоје штампани двојезични силабуси са тих предавања, нажалост нам нису били доступни, премда знамо на основу библиотечког каталога барем њихове наслове (Belić 1936); датуме смо допунили на основу другог извора (Anonym 1937): „Циљеви савремене лингвистике и њена основица” (20. марта), „Значај женевске лингвистичке школе за савремену лингвистику” (24. марта), „Традиционализам као сметња правилним лингвистичким схватањима” (23. марта), „Прасловенски језик и задаци његова проучавања” (датум није познат), „Реч и облик” са поднасловом „Њихов склоп” (26. марта) и на крају „Основи синтаксе” (27. марта). Дан касније је деканат Филозофског факултета у сарадњи са Словенским институтом у Прагу организовао пријатељску вечеру у част Александра Белића, и то у Палати Лопковиц на Малој Страни, седишту Словенског института. Предлог за ово вече потекао је од семинара за словенску филологију Филозофског факултета Карловог универзитета и потписују га два члана президијума овог семинара: Емил Сметанка (Emil Smetánka) и Милош Вајнгарт (Miloš Weingart), од којих је само Вајнгарт био члан Прашког лингвистичког кружока (Slovanský ústav: 57 - C 6/2).

Још пре Белићевог одласка одржан састанак руководства Словенског института (за дописног члана Института изабран је 1925. године), које је желело да Белић током свог боравка у Прагу одржи и једно предавање у овој институцији. За разлику од претходних предавања на универзитету, о припреми овог предавања знамо нешто више захваљујући сачуваној кореспонденцији у архиву Института (Slovanský ústav: 90 - F 2), као и у Музеју чешке књижевности у Прагу и Архиву САНУ у Београду (Линда 2017: 180-181, 185-187). Матија Мурко, тадашњи директор Словенског института и дугогодишњи пријатељ Александра Белића, позвао га је писмом од 19. фебруара да одржи предавање такође у Институту. Белић се 24. фебруара захвалио и понудио укупно три теме: „О почецима српскохрватске ћирилске писмености”, са тим што би говорио о „Мирослављеву јеванђељу, о књижевном раду Св. Саве и отварању Хиландарске школе”, затим „О значају чакавских дијалеката у Чехословачкој за историју српскохрватског језика” и предавање под називом „Лингвистика и средња школа". Мурко је у писму 3. марта Белићу захвалио за понуђене три теме и истовремено га упозорио да ће на вече и дебату у Словенском институту „доћи и лаичка публика, те би требало да се предавање тиче питања ширег значаја која би нас упознала [!] са односима у Југославији са словенског становишта". Стога је предложио да се предавање односи, на пример, на научне институције у Југославији. Белић је у благо нерасположеном тону у писму од 5. марта одговорио да разуме да би у Прагу желели нешто општију тему и извинио се што нема времена да припреми „из основа нешто ново”. Предложио је, међутим, три друга предавања: „Вук Караџић као отац српскохрватске националне културе”, са поднасловом „Са новим погледима о његовом раду”, затим „Из историје наше науке: Даничић - Јагић - Новаковић - Стојановић” и на крају трећу тему која се надовезује на Мурков предлог, и то „Српска краљевска академија за 50 година рада (1886-1936)”. Мурко у одговору од 12. марта Белићу захваљује и обавештава га да је президијум Словенског института одабрао прву од понуђене три теме, дакле о Вуку Караџићу. Истовремено му упућује молбу да „нарочито представи нове ставове о овом питању како 
би се о томе развила дискусија" и предлаже два термина за предавање - 2. април (тј. у четвртак, када су се по правилу одржавале дебате Словенског института), или 31. март. Тачан датум одржавања предавања је Белић сазнао тек након доласка у Праг, када му је Мурко у писму 20. марта саопштио да ће се предавање одржати у уторак 31. марта у Палати Лопковиц у 20 часова.

У истом писму је Белића такође позвао на свечану вечеру коју у његову част приређује Словенски институт у Друштвеном клубу у Прагу у улици На Пшикопје (Na Př́́kopě) 23. марта у осам сати увече. Тој вечери присуствовало је укупно 33 лингвиста и слависта, поред Мурка Јиржи Хорак, Франтишек Оперфалцер (František Operpfalcer), Јулијус Хајнденрајх (Julius Heindenreich) са супругом Јеленом (кћи писца Јозефа Холечека), Вацлав Важни (Václav Vážný), Јозеф Курц (Josef Kurz), Милада Паулова (Milada Paulová) и други (Slovanský ústav: 90 - F 2).

Занимљиво је да је Мурко самовољно променио наслов Белићевог предавања у „Вук Караџић и његово време” (Линда 2017: 187). Такође је Белића замолио да направи силабус предавања који би се делио слушаоцима, и како се тај захтев први пут појавио тек писму које је Белић добио после свог доласка у Праг, Белић је на брзину - на двама листовима хартије са знаком хотела Париз, у ком је био је био смештен - саставио извод предавања у 12 тачака и предао га Мурку. Мурко је дао да се препише и преведе на чешки језик па је умножени силабус у две верзије, чешкој и српској (са неколико грешака, од којих је најбитнија да уместо Стратимировић у штампаној верзији стоји Страшимировић) поделио учесницима. Рукопис је насловљен „Караџић као оснивач националне културе код Срба и Хрвата” (Slovanský ústav: 90 - F 2); с обзиром на то да је реч о досад непознатом тексту, прилажемо уз рад српску верзију силабуса (прилог бр. 2). Комплетан текст свог предавања према урађеном силабусу је Белић после повратка из Прага објавио у београдској „Правди”, и то под насловом који је предложио Матија Мурко (Белић 1936).

У Словенском институту чува се списак са именима учесника са овог предавања Александра Белића (Slovanský ústav: 90 - F 2); предавању је присуствовало најмање 65 слушалаца (у поређењу са другим предавањима у Институту ово је натпросечан број), међу њима су наравно били Олджих Хујер и Матија Мурко, те слависти и сорабисти Јозеф Пата (Josef Páta) и Антоњин Фринта (Antonín Frinta); Белићевом предавању о Вуку Караџићу су затим, поред колега који су били на поменутој вечери, присуствовали слависта Отон Беркопец (Oton Berkopec), директор прашког издаваштва Чешко-украјинска књига Хрихориј Омелченко (Hryhorij Omelčenko, етнограф Драхомира Странска (Drahomíra Stránská), археолог и историчар уметности Николај Лвович Окуњев, слависта Владимир Андрејевич Францев, Јевгениј Љацки и други. Вероватно не представља изненађење што нису присуствовали лингвисти из Прашког лингвистичког кружока.

Белићева посета Прагу 1836. године је природно била пропраћена бројним чланцима тадашње штампе; симптоматично је да су аутори често били стипендисти који су једно време провели у Београду слушајући његова предавања. Још пре његовог доласка, 7. марта 1936. Јиржи Хорак је објавио у немачком дневном листу „Prager Presse” опсежан чланак о контактима између Александра Белића и Томаша Гарика Масарика током Светског рата (Horák 1936a); у истим новинама је 20. марта (дан после његовог доласка у Праг) је био читаоцима Белић представљен у 
биографском чланку (Horák 1936b). О Белићевом боравку у Прагу и његовим предавањима у савременој штампи писао је између осталих и Јулијус Хајнденрајх. Према његовом мишљењу Белић је:

\footnotetext{
„изнео своје сопствено поимање језика и његових појава критички уздрмавши досадашње ставове владајуће Де Сосирове женевске школе. Белићева филозофија језика га изводи из уске и једносмерне улице лингвистичке праксе и води од 'материјалистичких' језичких појава ка духовним основама језика. Белићева излагања, изнесена и у оним најсложенијим питањима на класичан, једноставан и јасан начин, дивна су порука јужнословенске науке” (Heindenreich 1936).
}

На мартовски и априлски боравак у Прагу осврнуо се и Јозеф Пата у честитки за његов шездесети рођендан у августу 1936. године, присетивши се сусрета са њим:

„Радо се присећам тренутака проведених на часовима вежби на београдском универзитету, Белићевих занимљивих и поучних објашњења и упоређивања српског и чешког изговора, сећам се такође и изузетних тренутака беседа у Белићевом салону после светског рата 1921. године у Београду, тада још увек пуном трагова рата: у Белићевој библиотеци биле су књиге са мецима заривеним у корице јер се његова кућа налази на удару непријатељских напада" (Рáta 1936).

Јасно је да је чертнаестодневни боравак Александра Белића марта и априла 1936. године у Прагу био испуњен многим сусретима и састанцима о којима, нажалост, немамо сачуване архивске податке.

Треба напоменути да ово нису била једина путовања Александра Белића у Праг у периоду између два светска рата. Боравио је тамо још најмање два пута: у јуну 1935. године, када је дошао са кћери Цаном због њеног лечења код цењеног психијатра др Хуга Бондија (Hugo Bondy) у санаторијуму у Прагу-Бубенечу (Rotar 1990: 72). На основу његовог досијеа, сачуване у архиву Словенског института у Прагу, сазнајемо да је присуствовао сахрани првог чехословачког председника Томаша Гарика Масарика, 21. септембра 1937 (Slovanský ústav: 57 - C 6/2).

Кратко смо поменули планирано учешће чешких слависта на Трећем конгресу словенских филолога у Београду 1939. године (Станковић 2008). Како ово премашује оквир наше студије, радо бисмо макар упозорили на део до сада у истраживачке сврхе неискоришћеног фонда Словенског института у Прагу, који поседује, поред различитих предлога у вези са темама на конгресу (на пример предлог да се у програм скупа уврсти проблематика транслитерације ћирилице на латиницу, који је и прихваћен), такође спискове са именима учесника овог Конгреса, неколико пута мењане и допуњаване (Slovanský ústav: 300 - O 2/1).

Врхунцем професионалне каријере Александра Белића можемо неоспорно сматрати доделу почасног доктората Карловог универзитета 1946. године. О значају овог догађаја сведочи и чињеница је ово био први почасни докторат који је Карлов универзитет доделио једном странцу након Другог светског рата. О именовању за почасног доктора филозофије, очито на предлог Бохумила Хавранека, формално, међутим, на предлог сената Филозофског факултета, Белић је сазнао у 
јуну 1946 (Линда 2017: 154). Докторат му је додељен 26. октобра 1946. године у свечаном колегијуму максимуму Правног факултета. Белић је тада одржао предавање на тему „Моје схватање задатака лингвистике” (Slovanský ústav: 57 - C 6/2); поред овог предавања на свечаној додели доктората, одржао је током тадашњег боравка у Прагу још три предавања чији наслови нам нису познати (Sovilj 2008: 215). Чешка академија науке и уметности и Словенски институт организовали су затим у част Александра Белића свечану вечеру у ресторану фирме „Липерт” (Lippert), којој су између осталих, поред Хавранека и Хајнденрајха, били и југословенски амабасадор у Чехословачкој, Дарко Чернеј, и председник Чешке академије науке и уметности, Алберт Пражак (Slovanský ústav: 57 - C 6/2).

Као реакција на овај акт, без сумње, уследио је позив београдског универзитета (посредством Александра Белића) Бохумилу Хавранеку и Јулијусу Хајнденрајху да у децембру исте године одрже предавања у Београду. У периоду између 4. децембра, када су допутовали, и 8 . децембра, када су се прикључили чешким и словачким делегатима Словенског конгреса у Београду, њих двојица су одржали укупно пет предавања. Хавранек је тада у писму Белићу предложио три теме (међусловенски значај чешког књижевног језика, основна мерила груписања чешких дијалеката и социјални услови чешког књижевног језика), од којих је Белић изабрао прве две (Линда 2017: 151-152). Хајнденрајх је одржао предавања „О периодизацији српског националног романтизма”, „Чешка и словачка књижевност у борби за слободу и напредак народа” и „О новим методама у чешкој књижевној науци” (Burian 1947: 82).

Александар Белић је последњи пут посетио Праг 1948. године. Крајем месеца јануара учествовао је на званичном пријему у Тиршовој кући на Малој Страни, где су између осталих били присутни будући чехословачки председници Антоњин Запотоцки и Лудвик Свобода и тадашњи министри Здењек Неједли и Вацлав Копецки. После је био позван на вечеру код југословенског амбасадора, због које је прокоментарисао: „Жао ми је било што је тако испало, јер бих ја радије остао са Чесима - ради којих сам и дошао - неголи са нашима, које ми и иначе добро знамо” (Линда 2017: 158).

Други пут је био у Прагу 27. фебруара или 27. марта исте године. Наиме, у званичним документима Прашког лингвистичког кружока забележен је један и други датум и нисмо успели да основу других извора да прецизирамо који од њих је тачан (Čermák et al. 2012: 677). Белић је тада на сесији Кружока одржао предавање на тему „О књижевном језику - законитост у развоју словенских језика” (друго предавање је имао бугарски лингвиста Иван Леков) чији кратак сажетак је касније објављен у часопису „Slovo a Slovesnost” (Anonym 1950). Одговор на питање да ли је Белић био чланом Прашког лингвистичког кружока није сасвим једноставна; како смо видели, основни услов за чланство у виду одржаног предавања Белић је испунио још 1930. године. Како напомињу уредници овога издања, из сачуваних докумената не може увек са прецизношћу да се закључи, пре свега код иностраних лингвиста, да ли је дотични био чланом ПЛК-a (Čermák et al. 2012: 387-378). Међутим, управо ово Белићево предавање из 1948. године је за уреднике поменутог зборника докумената Прашког лингвистичког кружока било поводом да га наведу као члана ПЛК-а (Čermák et al. 2012: 389). 
Ово је заједно и последња Белићева посета Прагу. Мада је Белић планирао да се на кратко заустави у Прагу такође крајем августа исте године када се враћао из Вроцлава да би се састао са Видосавом Љацком, на крају се тада вратио директно у Београд (Линда 2017: 160, 167).

Како су међународни односи после проглашења Информбироа почели да се компликују, одразило се то и на универзитетску и академску сарадњу између Југославије и Чехословачке. Чешки лектор је опозван са београдског универзитета и престале су да стижу обимне пошиљке чешких и словачких књига, чији је број током година 1945-1948. на Катедри за источнословенске и западословенске језике чак премашивао број руских књига (Linda 2012: 518). Белић је у овом периоду послао телеграм честитке Матији Мурку за његов деведесети рођендан (остављамо по страни да је омашком поранио годину дана) и знамо такође за једно његово несачувано писмо Бохуславу Хавранеку из 1955. године, на које није добио одговор (Линда 2017: 165), тако да су се његови контакти са Прагом ограничили на више приватну кореспонденцију са Видосавом Љацком. Свакако вреди поменути и ове контакте јер они у најмању руку откривају непознате детаље из историје београдске бохемистике.

Видосава Љацка се родила у Крагујевцу у чешкој породици, са мајчине стране била је у даљем сродству са породицом Шафарик (Zahradníková 1997: 3). Од 1942, када јој је преминуо муж Јевгениј Александрович Љацки, професор на Карловом универзитету, живела је у Прагу сама. Била је, међутим, веома јако повезана са родном земљом и лично са Белићем, између осталог и због тога што је у периоду између два рата код њега студирала српскохрватски језик (заједно са руским).

Због тога је одлучила да се врати у Југославију и за помоћ се обратила емотивном молбом управо Белићу: „А сад сви чекамо, шта ћете нам Ви створити, Ви, који сте тако искусни организатор. Па ако се нађе тамо и неки рад за једну сироту смрзнуту жену у Прагу, која би хтела да ради и за свој српски народ, било би дивно" (Линда 2017: 166). Белић јој је понудио да буде „научни сарадник и секретар Института за источно и западно словенске језике и књижевности", чије оснивање је иницирао и припремао (Линда 2017: 159), при чему би њен главни задатак био рад на великом српско-чешком (!) речнику (Линда 2017: 168). Цела ствар је, међутим, наишла на проблем јер су чешки органи одбили да Љацкој, која је имала чехословачко држављанство, издају пасош потребан за пут. Белић је покушао да интервенише код чехословачког амбасадора Јиржија Тауфера „због тога што ћете Ви [тј. Љацка] радити овде на ширењу чешког језика и чешке културе”. Како Белић наставља, „он је све ово врло лепо прихватио и замолио ме да му о овоме дам забелешку. Ја сам му из Академије упутио званично писмо" (Линда 2017: 159).

Компликацијама око издавања пасоша је сигурно допринео и захтев чехословачке стране да са собом не сме узети никакву покретну имовину, која је пре свега представљала „дивна библиотека” њеног покојног супруга; Љацка је због тога одлучила да библиотеку прода београдском универзитету (Линда 2017: 168). У писму од 19. марта Белић Љацкој саопштава да је одговор чехословачке амбасаде „доста не- 
одређен и нејасан, али негативан. Они нам не могу дати радника на 'Чешко-српском речнику' зато што сами предузимају такав речник (под руководством г[осподи]на Хавранека); већ, напротив, траже од нас некога ко би им могао помоћи" (Линда 2017: 160). Додајемо да је тај речник изашао у Прагу 1982. године, његов главни аутор је био Јан Седлачек. У писму из маја 1949. године Белић је саопштио Љацкој

да је као привремени секретар именован Крешимир Георгијевић, док се цела ствар у вези са њеним доласком не реши и обавестио ју је да је рад на чешко-српском речнику (који је на крају изашао у Београду 2000. године) и пољско-српском речнику (изашао годину дана раније) већ започет (Линда 2017: 162).

Видосава Љацка није на крају дошла у Београд и није се, нажалост, укључила у рад поменутих речника. Све до свог одласка у пензију 1974. године предавала је у Државној школи за језике у Прагу. У последњем сачуваном писму Белићу из 1956. године Љацка се нада да ће Белић опет доћи у Праг ,јер се односи између наших двеју држава већ постепено нормализују" (Линда 2017: 169), али као што знамо, њена жеља се није испунила...

У овом раду смо покушали да дамо кратак преглед односа Александра Белића према чешкој славистици, нарочито прашкој, као једног од центара савремене модерне лингвистике. Иако није поједине постулате Прашког лингвистичког кружока није прихватао и формално је био чланом Кружока тек од 1948. године, могуће га је сврстати у шири круг ПЛК-а већ од почетка 30. година 20. века. Неоспоран је његов утицај на чехословачку југославистику - многи његови београдски студенти из Чехословачке имали су пресудан утицај на послератно формирање овог струке у послератној Чехословачкој. Уз то је очигледно да је Белића за Праг и Чехословачку везивао надстандардан однос као другом центру руске послеоктобарске емиграције. Несумњиво и с правом сврставамо Александра Белића међу лингвисте светског формата који су на преломан начин учествовали у формирању славистичке филологије и утицали на њен смер који и данас представља наше полазиште.

\section{Прилози}

\section{Прилог бр. 1.}

Резолуција Комисије за функционално-структурално истраживање словенских језика из 1929. године (објављено на српском језику у: Ročenka Slovanského ústavu v Praze 4 (1932): стр. 251).

\section{О примјењивању функционалног-структуралног испитивања језика}

1) I. конгрес словенских филолога у Прагу утврдио је важност примене и синхроног и дијахроничног метода у испитивању језичких факата. Он је нашао да нема у томе правцу принципских разлика између словенске лингвистике и других модерних лингвистика. 
2) Пошто функционално-структурално (а специјално синхронично) испитивање није створило још потпуно утврђен систем научног испитивања, то се мора оставити појединцима да продуже ова испитивања; али се нарочито препоручује паралелни рад: и на оваквом проучавању словенских језика и на израђивању дефинитивног система оваквог начина испитивања.

3) Оба метода рада, дијахронични (историјски) и синхронични, допуњују се узајамно. Од циља научних испитивања зависи да ли ће се само један од њих употребити, оба наизменице или оба у исто време.

4) Конгрес одлучује да комисија која је ову резолуцију саставила остане и даље у важности, са задатком, да спрема материјал из ове области испитивања за нови конгрес словенских филолога и да се брине о вези оваквих студија у области словенских језика са сличним студијама у области несловенских језика.

Чланови Комисије: Белић (Београд), Дорошевски (Варашава), Хавранек (Брно), Јакобсон (Праг), Карцевски (Женева), Матезијус (Праг), Нич (Краков), Романски (Софија), Симович (Праг), Трубецки (Беч).

\section{Прилог бр. 2.}

Александар Белић: Караџић као оснивач националне културе код Срба и Хрвата. Синопсис предавања одржаног у Словенском институту у Прагу 31. марта 1936. године (оригинални аутограф у Масариковом институт и Архив Академије наука ЧР у Прагу, фонд Словенски институт, инв. бр. 90, сигн. F 2, кутија 18).

1) Борба војвођанских духовних и књижевних кругова за славеносербски језик имала је основицу у политичко-националним приликама у осамнаестом веку.

2) Та је борба изашла са два постулата који се уносе у XIX в.: рушења црквене (или руске) ћирилице и тражење чистог народног језика - једнако је издаји народних интереса.

3) Караџић, човек из земље која се бори за слободу и независност, није могао разумети и није хтео разумети да народ који ствара слободну државу нема права да ствара своју културу.

4) Да би се оградио од напада да је његова реформа антируска или чак русофопска, Караџић већ 1819. год. одлази у Русију и успева да она одобри његову реформу.

5) Караџић и Копитар. Копитар се радовао да се Јужни Словени Вуковом реформом одвоје од туторства Русије, јер је тако мислио да ће се они пре ујединити у моћну словенску државу под Аустријом, али није био прозелита. Он помаже да Вука призна Русија.

6) Борба Вукова против пречанских војвођанских власти није могла имати успеха до 1836. год., докле год је био жив митрополит Стратимировић, који је сав поникао из борби XVIII века и који је тада формирао свој менталитет.

7) Караџић се уверава да његова реформа може победити у Србији или Црној Гори, које су биле далеко од војвођанског менталитета. Али се преварио. 
Србија је била под утицајем Војводине, а Црна Гора се за те ствари није интересовала.

8) Он покушава да се приближи Милошу Обреновићу и Његошу, али узалуд.

9) Умире Стратимировић, али његов фронт остаје. Вук удара по њему, слаби га, али осећа да се сада Војводина наслања на Србију, која продужава традиције Стратимировићеве.

10) И све докле се год није Србија ослободила и Турака и културних утицаја Стратимировићевих, а то је дошло са другом владом кнеза Михаила Обреновића, дотле и Вук није победио. Почетак победе 1859. и крајња победа 1868. (марта мес.).

11) Караџић је поникао у време романтизма, али је сам био реалиста. Он је сматрао да ослобођени народ - мора имати и своју народну културу. Он није одобравао ни рад Доситејев.

12) Караџић је изнад свих појединачних праваца свога времена. Он је творац народне културе према историјској неопходности: друкчије се народ из своје културе искључивао. Зато се по огромноме значају за српскохрватску културу нико, па ни Доситеј, не може са њим мерити.

\section{Извори}

Досије Александра Белиће, инв. бр. 57, сигн. С 6/2, кутија 13.

Masarykův ústav a Archiv Akademie věd ČR, fond Slovanský ústav (Масариков институт и Архив Академије наука ЧР, фонд Словенски институт):

Предавање Александра Белића 1936. године, инв. бр. 90, сигн. F 2, кутија 18.

Трећи међународни конгрес слависта у Београду 1939. године, инв. бр. 300, сигн. О 2/1, кутија 37.

\section{Литература и извори}

Белић А. „Kroaten und Serben von Prof. Dr. M. Murko (Graz).” Засебно одштампано из „Österreichische Rundschau”, IX. 4. 235-248. Српски књижевни гласник, књ. XVIII, св. 1 (1907): стр. 66-67.

Белић А. „О прасловенском језику.” Slavia, 1 (1922): стр. 8-11.

Белић А. „Úvod do dějin jazyka českého / Oldřich Hujer. - 2. vyd. - Praha, 1924. - 91.” Јужнословенски филолог, 4 (1924): стр. 213-215.

Белић А. „Први конгрес словенских филолога у Прагу 1929. год. од 6-13. октобра.” Јужнословенски филолог, 8 (1929): стр. 160-178.

Белић А. „Олджих Хујер.” Јужнословенски филолог, 9 (1930): стр. 316-318.

Белић А. „Фонолошка конференција у Прагу од 18. до 31. децембра 1930. г.” Јужнословенски филолог, 10 (1931): стр. 188-190.

Белић А. „О словенској лингвистичкој библиографији.” Horák J. et al. (ур.). Sborník prací I. sjezdu slovanských filologů v Praze 1929. Sv. II. Přednášky. Praha, 1932: стр. 966-977. 
Белић А. „Караџић и његово време.” Правда, 11-14. 04. 1936: стр. 4.

Линда J. „Преписка Александра Белића с научницима у Чехословачкој.” МршевићРадовић Д., Сувајџић Б., Танасић С. Александар Белић, српски лингвиста века. Кь. 2, Александар Белић и страни слависти. Под кровом Српске академије наука и уметности. Београд: Филолошки факултет Универзитета - Чигоја штампа, 2017: стр. 147-191.

Совиљ М. Југословенско-чехословачке културне везе и односи 1945-1950. Београд: Универзитет у Београду, Филозофски факултет, Катедра за историју Југославије, 2008.

Станковић Б. (ур.). III међународни конгрес слависта (Београд, 18-25. IX 1939). Београд: Славистичко друштво Србије, 2008.

Хујер О. „Чешка филологија и лингвистика од 1909-1921. год.” Јужнословенски филолог, 3 (1922-1923): стр. 112-137.

„Anonym Návštěvy hostí v Slovanském ústavu." Ročenka Slovanského ústavu v Praze za rok 1936, 9 (1937): s. 88.

„Anonym: Přednášky v Pražském linguistickém kroužku.” Slovo a slovesnost, 12 (1950): s. 55.

Belić A. „Sur l'accent du mot et de la phrase.” Travaux du Cercle lingvuistique de Prague, 4 (1931): s. 183-188.

Belić A. Obsahy přednášek. Изводи предавања. Praha: Seminář pro slovanskou filologii University Karlovy v Praze, 1936.

Burian V. „Kronika Slovanského sjezdu v Bělehradě.” Slovanský přehled, 38 (1947): s. $60-82$.

Čermák P., Poeta C., Čermák J. (eds.). Pražský lingvistický kroužek v dokumentech. Praha: Academia, 2012.

Heindenreich J. „Prof. Aleksandar Belić v Praze.” Československo-jihoslovanská revue, 6 (1936): s. 32-33.

Horák J. „Aleksandar Belić in Prag.” Prager Presse, 19. 03. 1936: s. 7.

Horák J. „Keime der Kleinen Entente. Masaryks Zusammenarbeit mit Alexander Belić.” Prager Presse, 07. 03. 1936: s. 7-8.

Linda J. „Historie a struktura českého fondu knihovny katedry slavistiky FF BU.” Славистика, 16 (2012): s. 515-530.

Páta J. „PhDr. Alexandr Belić, vynikající srbský slavista, profesor slovanské filologie na jugoslávské universitě v Bělehradě, dovršil právě šedesáti let.” Národní politika, 06. 08. 1936: s. 8.

Rejnková R. I. sjezd slovanských filologů v Praze 1929. Bibliografie. Praha: Státní knihovna Československé socialistické republiky - Slovanská knihovna, 1968.

Rotar J. Korespondenca med Franom Ramovšem in Aleksandrom Belićem. Ljubljana: Slovenska akademija znanosti in umetnosti, 1990.

Toman J. Angažovaná čitanka Romana Jakobsona. Články, recenze, polemiky 1920-1945. Praha: Karolinum, 2017. 
Zahradníková M. Vidosava Ljacká (1903-1991). Soupis osobního fondu. Praha: Literární archiv Památníku národního písemnictví - Slovanský ústav, 1997.

\author{
Яромир Л. Линда
}

АЛЕКСАНДР БЕЛИЧ И ЧЕШСКАЯ СЛАВИСТИКА

Резюме

В работе мы обращаем внимание на отношения между Александром Беличем и чешскими славистами (Богуслав Гавранек, Юлиус Гайнденрайх, Вилем Матезиус, Йиржи Горак), а также славистами, которые в тот период жили в Чехословакии (Матиаш Мурко, Евгений Александрович Ляцкий и его супруга Видосава Ляцкая). При этом мы исходим, в первую очередь, из неопубликованной переписки, которая хранится в чешских и сербских архивах и тогдашней печати. Особое внимание уделяется пребыванию Александра Белича в Праге в 1936 году, когда он прочитал несколько лекций в Славянском институте и в Карловом университете, а также его отношению к Пражскому лингвистическому кружку (ПЛК). Хотя он не принял отдельные постулаты Пражского лингвистического кружка и стал формально его членом лишь с 1948 года, его можно отнести к более широкому кругу ПЛК уже с начала 30-х годов XX века. В приложении к работе публикуется текст Резолюции Комиссии по функционально-структуральным исследованиям славянских языков 1929 года, а также конспект лекции о Вуке Караджиче 1936 года.

Ключевые слова: Александр Белич, Карлов университет в Праге, Славянский институт в Праге, Пражский лингвистический кружок, Богуслав Гавранек, Юлиус Гайнденрайх, Вилем Матезиус, Йиржи Горак, Матиаш Мурко, Евгений Александрович Ляцкий, Видосава Ляцкая. 